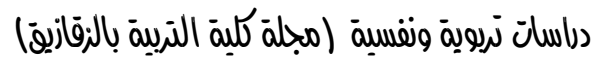

\title{
The intercultural competence savoirs in the third year secondary level English textbook: 'Hello! English for Secondary Schools'
}

\author{
Dr Samia Kara \\ Department of English and Scientific Methods, \\ GUC, Egypt
}

samia.kara@guc.edu.eg

تقدم هذه الورقة تقريرا عن تقييم كتاب اللغة الإنجليزيـة للسنة الثالثة ثانوي "مرحبـا

\section{Abstract:}

This paper reports on an evaluation of the third year secondary level English textbook 'Hello! English for Secondary Schools' in terms of intercultural competence within its 'savoirs' sub-category. A question was raised in relation to the presence of intercultural competence savoirs at the level of the goals/objectives, texts, illustrations and activities/tasks. A mixed method based conceptual content analysis with some relational features was undertaken. The results have shown that this ingredient is present in terms of intercultural attitude enhancement, cultural topics and 
information, students' active engagement and teaching aids/ illustrations. However, they have also revealed that the little culture ingredient has been marginalised for the benefit of the big culture as part of the requirements of the standards-based approach connections umbrella. It was recommended that it gets reviewed for the sake of enriching its intercultural components with more little culture ingredients.

Keywords:Teaching English, intercultural competence, textbook evaluation.

\section{Introduction}

Due to its cumulative history and after the Second World War, English as a language has reached an overwhelming spread all around the world in terms of roles and uses. Consequently, many linguists have endeavoured to draw a picture of its universal authority and the result was a set of suggestions that attempted to categorise it in terms of models:

- The tri-partite: ENL (English as a native language), ESL (English as a second language), and EFL (English as a foreign language).

- The three concentric circles: the inner circle (primary language of a country), the outer circle (additional language in the country), and the expanding circle (foreign language).

- The dimensions: the degree of standardisation, degree of codification and domains of use are considered. (Quirk, Greenbaum, Leech \& Starvik 1985, Krachu 1985, Melchers \& Shaw 2003; cited in Davydova, 2012, p.366).

Taking into account the aforementioned models, it might be inferred that English as a norm is no longer restricted to its 
native speakers. This idea is very much reinforced by the fact that globalisation has made it possible for many people with different background native languages to use English as a lingua franca for the sake of exchanging - along the language itself, cultural knowledge pertaining not only to the host language (English) but to all the other native languages.

Under those consequences, a paradigm shift in research interest took place in the fields of second language acquisition and foreign language learning. It made it clear that culture does contribute to individual features in terms of socio-cultural variables (Arabski \& Wojtaszek, 2011). This is what compels, today, learners to acquire skills in relation to behaving interculturally as they are to communicate with English native speakers as well as speakers of different native languages (Nizergorodcew, 2011).

Henceforth, English is no longer the property of its inner circle only but the one of expanding ones that may not include native speakers. Accordingly, there exists a "third place" (Kramsch, 1993) wherein learners express their cultural backgrounds and show readiness to understand others' ones; and any correlation between a language with its nation's only culture is to be viewed as an unrefined oversimplification (Baker, 2009). Indeed, learners must deal with their first language culture, their foreign language culture and their interlocutors' culture in terms of contexts (Piasecka, 2011). This is what might be referred to as 'recul' or 'distancing' meaning a situation wherein one's interest in and acquaintance with otherness are encouraged through a negotiation of dis/similarities and a comprehension of others' perspectives without losing one's own (Lomicka, 2009). Fulfilling this requires a set of skills grouped into one body called 'intercultural competence'. 
Egypt, and as part of the globalised village, faces the challenge of expanding its secondary school students' intercultural competence as foreign language needs have grown numerous and diverse. Indeed, the students and after fulfilling this level might encounter life choices be they academic, vocational or professional wherein this intercultural knowledge is of great demand especially in international contexts at home and abroad. Thus and considering the situation of English as a foreign language in Egypt, this paper aimed at evaluating the presence and extent of intercultural competence savoirs - i.e., knowledge of the culture, in the third year secondary level textbook: 'Hello! English for Secondary Schools' for it is the most explicit component of the whole teaching/learning situation used by both students and teachers. More specifically, the paper sought to answer the question: To what extent is the intercultural competence (as savoirs) present in the textbook at the level of goals/objectives, texts, activities/tasks and teaching aids (illustrations)?

\section{Literature review}

\subsection{Intercultural competence}

To tackle the issue of intercultural competence (IC), the starting idea is always the word competence itself which refers mainly to one of its ingredients, namely, knowledgeability in some field (Karyshev, Karysheva \& Ivanova, 2014). Accordingly, any competence is mainly a sum of ingredients rooted back in cognition (knowledge), function (application), person (behaviour) and ethics (principles), and which make out of the toning of the capacity of knowing and that of speaking and acting accurately in contexts a must (UNESCO, 2013, p. 12). 
IC is 'the appropriate and effective management of interaction between people who, to some degree or another, represent different or divergent affective, cognitive, and behavioural orientations to the world' (Spitzberg and Changnon, 2009, p.7). In other words, people who come from different cultural backgrounds differ in three domains, namely, affection, cognition and behaviour; and they need to be competent enough to go beyond these differences and interact effectively with one another. Correspondingly, any change to be made for the sake of this goal must be at the psychological level and targeting proper attitudes toward cultural variances (Cheng, 2012).

According to UNESCO (2013), words like literacy, responsibility, reflexivity, liquidity, creativity, shifting, disposition, semantic availability, conviviality and resilience contribute to the notion of IC. Besides, IC encompasses individual abilities such as empathy, open mindedness, and cultural knowledge as well as related contextual variables such as shared goals and incentives (Arasaratnam, 2016).

In their efforts to handle the issue of IC, several attempts were made by different scholars and the result came in the form of five models described by Spitzberg and Changnon (2009, pp.7-35):

- compositional model and it pinpoints appropriate attitudes, skills and knowledge;

- co-orientational model and it describes communication in intercultural interactions by virtue of constructed perceptions, meanings and intercultural understandings;

- developmental model and it identifies the stages of IC development; 
- adaptational model and it pinpoints the processes whereby individuals adapt their knowledge, attitudes and behaviours in contact with cultural otherness; and

- causal path and it identifies particular causal relationships among the various ingredients of IC.

To conciliate these trends, Deardoff (2011, p. 67) attempted to specify the elements that won consensus, namely, attitudes, knowledge, skills as well as internal and external outcomes. She further placed them in a visual process based framework made of the components:

- attitudes which include respect, openness, curiosity and discovery;

- knowledge that is concerned with comprehending the deep knowledge of culture as well as its specific information;

- skills which include observation, listening, evaluating, analysing, interpreting and relating for the sake of acquiring and processing knowledge;

- internal outcomes that are the result of attitudes, knowledge and skills and include flexibility, adaptability, ethnic based perspective, and responsiveness; and

- external outcomes which are the result of attitudes, knowledge and skills as well as internal outcomes and represent behavioural and communication conducts of the individual.

Deardorff (2011) additionally insisted that the framework is to be considered in relation to lifelong processes and that it is not sufficient in itself as it mainly came out of US centric viewpoints. She further explained that other extra US views included the perspective of relationship in IC, historical as well 
as social and economic contexts, role of identity and need for cultural humility.

IC presupposes also the presence of a readiness to know in terms of having a pertinent knowledge in relation to specific cultures (UNESCO, 2013). Besides, it also assumes the existence of a general understanding about what happens when culturally different individuals interact, bearing in mind the approachable attitudes that enhance the creation and preservation of contact with others (UNESCO, 2013). The UNESCO (2013, p.13) adopted this knowledge which was divided by Byram (1997) into five types:

- Savoirs (knowledge of the culture),

- Savoir comprendre (skills of interpreting/relating),

- Savoir apprendre (skills of discovery/interaction),

- Savoir être (attitudes of curiosity/openness), and

- Savoir s'engager (critical cultural awareness).

The said 'savoirs' go hand in hand with the third of the four UN education pillars 'learning to live together', and can be seen as being in relation to the principles guiding intercultural education:

- respect of the learners' cultural identity,

- provision of the necessary knowledge, attitudes and skills for the sake of an active participation in the society, and

- the outcomes of the second principle being the impact on individuals as well as ethnic/cultural/ social/ and religious groups in terms of respect and mutual comprehension and solidarity (UNESCO, 2013, p.27). 
Thus and for IC to be fulfilled, concerned institutions, namely, educational systems, legal systems and other informal institutions must be involved for the benefit of both the individual and the society (UNESCO, 2013).

In association with IC and in relation to language learning, the concept of intercultural communicative competence (ICC) has been introduced. In fact, ICC is regarded as an advanced step of IC; that is to say, if the latter requires that interaction takes place in one's own language with individuals from another country and culture, ICC necessitates that the same interaction takes place in a foreign language (Byram, 1997). Therefore, the differentiation made between the two should be well assumed (Lopez-Rocha, 2016). Conversely, IC and ICC are also used interchangeably especially in communication literature (Arasaratnam, 2016).

\subsection{Evaluating textbooks for intercultural competence}

Evaluating textbooks in relation to culture/ interculture in general was the subject of several attempts. For example, Kim \& Paek (2015) used themes as criteria specifying them in terms of big ' $\mathrm{C}$ ' (music, literature, arts...) and little ' $\mathrm{c}$ ' (food, fairs, fashion...). This dichotomy is in accordance with Brooks' (1968) view of culture as being formal (mainly seen in the features of the social group and of which the individual is aware) and deep (individual's adaptation of his/her behaviour -eating, dressing..., thinking, believing and valuing to the surrounding group). The same dichotomy concords with Hofstede's (1980) first and second culture, Lafayette's (1997) big C culture and little c culture, and Neuner's (2012) elitist culture (achievement 


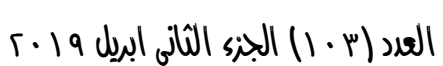

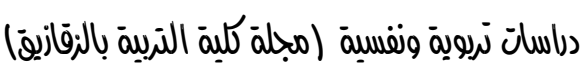

of art and scholarship) and everyday culture (everyday phenomena).

Kim \& Paek (2015) also used Cortazzi \& Jin's (1999) categories of culture, namely, source culture (SC), target culture (TC) and international culture (In.C) to analyse content reference in textbooks. In addition, these same authors made use of Moran's (2001) classification of culture into products (artifacts, places, institutions, and art forms), practices (operations, acts, scenarios, and lives), perspectives (explicit/implicit perceptions, beliefs, values and attitudes), communities (specific social contexts and groups) and persons (individual members embodying the culture) to evaluate cultural dimensions in textbooks.

Another attempt made for the sake of evaluating textbooks from the intercultural point of view is that of Shardakova and Pavlenko (2004) who focused on identity representations in Russian textbooks designed for the benefit of American students.

For their part and investigating the presence of IC in the last fifty years and in English business textbooks (1963-2009), Lario De Onate \& Vasquez Amador (2013) followed a scheme that consisted of depicting the existence of the concept itself, its level of importance (whole units, sections and activities) and teaching methodology within the units in terms of verbal/ nonverbal communication based activities.

Another contibution is that of Homayounzadeh \& Sahragard (2015) who used the first four identity options out of Ting-Toomey's (1998) eight options (cultural, ethnic, gender, personal, role, relational facework and symbolic) to analyse textbooks in Iran. They also made use of discourse structures emphasizing the concepts of face saving and politeness strategies. 
In an attempt to synthesise the benchmarks used for textbook evaluation, Liu (2016) gathered the criteria developed by twenty sources (Reinman, 2009; Byram et al., 2002; Kilickaya, 2004; Cunningsworth, 1995; Chen, 2012: Chen, 2011; Xiao, 2010; Wu, 2010; Chen, 2010; Lee, 2009; Yamanaka, 2006; Lu, 2006; Moran, 2001; Sercu, 1998, Byram, 1997; Byram et al., 1994; Kramsch, 1993; Kachru, 1992; Huhn, 1978 and Widdowson, 2005) in five scopes: goals/objectives (criteria of cultural knowledge, communication and intercultural attitude), cultural topics (criteria of relevance, interest, and diversity), cultural information (criteria of types of culture, cultural sensitivity, perspective and representation, authenticity and presentation), cultural activities (student participation, familiarity and logistics), and teaching aids (illustrations and images, teacher's manual and supplementary teaching resources).

Ahmed and Narcy-Combes (2011) investigated the representation of the learner's culture through pictures in textbooks used in Pakistan and by foreign authors (protagonism, passivity, status, body language, clothing and eyes direction) as well as the learner' cultural stereotypes and the textbook authors' sensitivity.

Additionally and just as interesting as the previous endeavour is that of Ajideh and Panahi (2016, p.9) who focused on the use of pictures in textbooks culture wise and in relation to

- pictures with culture specific reference to native culture (PCSR),

- pictures with culture free reference wherein no reference to any culture is made (PCFR),

- pictures with culture general reference wherein the input is common to all cultures (PCGR), and 
- pictures with target culture references to foreign cultures -English or Non-English speaking countries (PTCR).

All these efforts do show that the foci of evaluation direct the choice of cultural aspects to be assessed. They also show that IC is a maltifaceted concept that undergoes many pathways when investigated in textbooks.

\section{Methodology}

\subsection{Research design}

The method adopted is content analysis (Carley, 1992) that is mainly conceptual with some relational features. Thus, it falls within a mixed method frame as it uses both qualitative and quantitative procedures for validation purposes (Creswell, 2011).

Since IC is made of blocks of knowledge (UNESCO, 2013), the selection opted for was that of knowledge of the culture (savoirs) as it is the only one available through the textbook for measurement. The other savoirs would require the students, teachers, administrators as sources of data, a circumstance that overexceeds the present paper.

\subsection{Procedure}

\subsubsection{Data}

The textbook in its pdf format was retrieved from its website:

$<$ http://elearning1.moe.gov.eg/sec/semester1/Grade3/pdf/english _3sec_dlil.pdf $>$.

It was turned into a doc format and through the 'review tab) new comments' command was annotated. Then, the comments were extracted using a macro for microsoft word available

on: 
'https://www.thedoctools.com/index.php?show = macros\&lang $=\mathrm{u}$ s'. The results were, then, summarised into tables with statistical features and figures.

\subsubsection{Framework and coding}

The evaluation framework targeted the textbook in terms of its components:

- goals and objectives,

- texts (listening transcripts and reading passages),

- activities/ tasks that are present in the critical thinking section, and

- teaching aids embodied in illustrations.

It followed the criteria cited in Liu (2016, p. 843-844):

- intercultural attitude in terms of cultural knowledge (Byram et al., 2002),

- cultural topics in terms of diversity (Cunningsworth, 1995),

- cultural information in terms of types of culture (Chen, 2012),

- cultural activities in terms of students' active participation (Reimann, 2009), and

- teaching aids in terms of illustrations and images (Reimann, 2009).

The coding for listening transcripts and reading passages was:

- BC for big culture and Lc. for little culture (Theme reference) 
- SC for source culture, TC for target culture and In.C for international culture (content reference)

- products, practices, perspectives, communities and persons (dimensions).

The coding for illustrations was:

- PCSR for specific reference to native culture

- PCFR for free reference

- PCGR for general reference

- PTCR for foreign cultures reference.

The coding for students' active engagement was:

- SC for source culture reference

- TC for target culture reference

- In.C for international culture reference

\section{Results}

\subsection{General description}

Published in 2010 by the Egyptian International Publishing Company- Longman and authored by Simon Haines and Don Dallas, the textbook is entitled: 'Hello! English for Secondary Schools'. It targets grade 12 and comes in the form of 18 units separated by six revision sections in addition to one grammar review division. It also comes in 144 pages with a ratio of five pages per unit. Each unit is made of five parts, namely, 'Listening', 'Language Focus', 'Reading', 'Critical Thinking' and 'Communication'. The textbook is accompanied with a workbook, a website (www.longmansec.com.eg), a teacher's guide, a reader, a revision CD-ROM as well as course cassettes. 


\subsection{Goals and objectives}

As claimed by the author in the teacher's guide and within the section entitled The Aims of the Course, 'The course is standards-based and it aims to fulfil the standards set out in the Ministry of Education Standards Document' (Stannard, n.d., p.1). The Ministry of Education Standards Document is a framework that was developed by a group of Egyptian experts for the sake of guiding textbook writers, teachers and school leaders to carry out the EFL curriculum (El-Araby et al., 2012, p.5). It is based on research pertaining to language education as well as the National Authority of Quality Assurance and Accreditation of Education (NAQAAE) standards for foreign language learning (El-Araby et al., 2012, p.9).

As the textbook targets grade 12, it is supposed to go hand in hand with the aims of the English curriculum for the secondary stage. These are mainly concerned with strengthening learners' understanding of foreign cultures and societies with the view of increasing mutual understanding beyond national boundaries for the sake of global citizenship sense enhancement (El-Araby et al., 2012, p.8). The following table 1 exhibits the EFL culture related standards altogether with their learning outcomes for grade 12 (El-Araby et al., 2012, pp.15-84).

Table 1. Culture related standards and learning outcomes for grade12

\begin{tabular}{|c|c|c|}
\hline Domain & Standard 4 & Learning outcomes for grade 12 \\
\hline Listening & $\begin{array}{l}\text { Learners gain } \\
\text { knowledge and } \\
\text { understanding of } \\
\text { target cultures }\end{array}$ & $\begin{array}{l}\text { Demonstrate understanding and } \\
\text { appreciation of argumentative multi-media } \\
\text { texts from various English speaking } \\
\text { cultures }\end{array}$ \\
\hline
\end{tabular}




\begin{tabular}{|c|c|c|}
\hline & through listening. & $\begin{array}{l}\text { - React to patterns of interactions from } \\
\text { various cultures showing tolerance and } \\
\text { acceptance in a multi-media text } \\
\text { - Understand non-verbal social } \\
\text { conventions that characterise both the } \\
\text { national and target cultures } \\
\text { - Appreciate the similarities and } \\
\text { differences between the values, beliefs } \\
\text { and practices of both the national and } \\
\text { international cultures through multi- } \\
\text { media expository (factual) texts. }\end{array}$ \\
\hline Speaking & $\begin{array}{l}\text { Learners } \\
\text { understand the } \\
\text { practices and } \\
\text { values of both } \\
\text { national and target } \\
\text { cultures. }\end{array}$ & $\begin{array}{l}\text { - Engage in age-appropriate argumentation } \\
\text { of cultural issues } \\
\text { - Express an awareness of } \\
\text { positive/negative cultural issues } \\
\text { - Explain social and democratic practices } \\
\text { - Reflect on how change affects cultural } \\
\text { aspects in expository texts. }\end{array}$ \\
\hline Reading & $\begin{array}{l}\text { Learners } \\
\text { understand the } \\
\text { practices and } \\
\text { values of both } \\
\text { national and target } \\
\text { Cultures. }\end{array}$ & $\begin{array}{l}\text { - Read about positive/ negative cultural } \\
\text { issues } \\
\text { - Read about social, democratic, political } \\
\text { and economic issues in both national and } \\
\text { international cultures } \\
\text { - Read expository texts on how change } \\
\text { affects social, political, economic and } \\
\text { cultural aspects in a given society. }\end{array}$ \\
\hline Writing & $\begin{array}{l}\text { Learners } \\
\text { demonstrate } \\
\text { awareness of the } \\
\text { practices and values } \\
\text { of both national and } \\
\text { target cultures } \\
\text { while writing. }\end{array}$ & $\begin{array}{l}\text { - Write short simple sentences about } \\
\text { cultural practices in their own culture and } \\
\text { the target culture } \\
\text { - Express sense of belonging to } \\
\text { immediate, local, and national community. }\end{array}$ \\
\hline
\end{tabular}


The author also maintained in the teacher's guide and always within the section entitled The Aims of the Course, that:

'The course uses a standards-based communicative approach and methodology for the teaching and learning of English. Students are presented with interesting topics and meaningful situations to help them to progress in their secondary-level language skills. They use and integrate the four language skills (listening, speaking, reading and writing) in meaningful contexts and undertake realistic language tasks which they would potentially undertake in future academic, professional or vocational situations' (Stannard, n.d., p.1).

\subsection{Texts}

Both of the listening transcripts and reading passages have been analysed in terms of theme reference, content reference and dimensions. The results are displayed in table 2 .

Table 2. Theme reference, content reference and dimensions in texts

\begin{tabular}{|c|c|c|c|c|}
\hline Unit & Texts: Listening/ Reading & $\begin{array}{c}\text { Theme } \\
\text { Referen } \\
\text { ce }\end{array}$ & $\begin{array}{c}\text { Content } \\
\text { Referen } \\
\text { ce }\end{array}$ & Dimensions \\
\hline 1 & $\begin{array}{c}\text { Space Travel/ Space } \\
\text { Tourism }\end{array}$ & $\mathrm{BC}$ & $\begin{array}{l}\text { In.C \& } \\
\text { SC }\end{array}$ & $\begin{array}{c}\text { Products/ } \\
\text { Perspectives }\end{array}$ \\
\hline 2 & $\begin{array}{l}\text { Writer Anthony Hope/ } \\
\text { The Prisoner of Zenda }\end{array}$ & $\mathrm{BC}$ & $\mathrm{TC}$ & $\begin{array}{l}\text { Practices/Persons/ } \\
\text { Perspectives }\end{array}$ \\
\hline 3 & Energy/ Energy & $\mathrm{BC}$ & In. C & $\begin{array}{c}\text { Products/ } \\
\text { Perspectives }\end{array}$ \\
\hline 4 & $\begin{array}{c}\text { A Talk by a Writer/ Yehia } \\
\text { Haqqi }\end{array}$ & $\mathrm{BC}$ & $\mathrm{SC}$ & $\begin{array}{c}\text { Practices/Perspectiv } \\
\text { es/ Persons }\end{array}$ \\
\hline 5 & $\begin{array}{l}\text { A Talk about Agatha } \\
\text { Christie/ } \mathrm{N} \text { or } \mathrm{M}\end{array}$ & $\mathrm{BC}$ & $\mathrm{TC}$ & $\begin{array}{c}\text { Practices/Perspectiv } \\
\text { es/ Persons }\end{array}$ \\
\hline
\end{tabular}




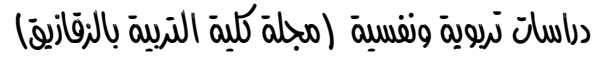

\begin{tabular}{|c|c|c|c|c|}
\hline Unit & Texts: Listening/ Reading & $\begin{array}{c}\text { Theme } \\
\text { Referen } \\
\text { ce }\end{array}$ & $\begin{array}{l}\text { Content } \\
\text { Referen } \\
\text { ce }\end{array}$ & Dimensions \\
\hline 6 & $\begin{array}{c}\text { A Radio Program about } \\
\text { Trees/ Why do we Need } \\
\text { Trees? }\end{array}$ & $\mathrm{BC}$ & In. C & $\begin{array}{c}\text { Products/ } \\
\text { Perspectives }\end{array}$ \\
\hline 7 & $\begin{array}{l}\text { Cairo Underground System/ } \\
\text { Great Engineering }\end{array}$ & $\mathrm{BC}$ & $\begin{array}{l}\mathrm{SC} \& \\
\text { In. C }\end{array}$ & $\begin{array}{c}\text { Products/ } \\
\text { Perspectives }\end{array}$ \\
\hline 8 & $\begin{array}{c}\text { A Radio Program about } \\
\text { Robert Louis/ Dr Jekyll and } \\
\text { Mr Hyde }\end{array}$ & $\mathrm{BC}$ & $\mathrm{TC}$ & $\begin{array}{c}\text { Products/ } \\
\text { Perspectives } \\
\text { Persons }\end{array}$ \\
\hline 9 & $\begin{array}{c}\text { The Power of Nature/ } \\
\text { Unusual Weather }\end{array}$ & $\mathrm{BC}$ & In. $\mathrm{C}$ & $\begin{array}{c}\text { Products/ } \\
\text { Perspectives }\end{array}$ \\
\hline 10 & $\begin{array}{c}\text { A Conversation between } \\
\text { Two Students/ Food from } \\
\text { the Air }\end{array}$ & $\mathrm{BC}$ & In. C & $\begin{array}{l}\text { Products/ } \\
\text { Perspectives }\end{array}$ \\
\hline 11 & $\begin{array}{c}\text { A Talk about Alexander } \\
\text { Dumas/ The Count of Monte } \\
\text { Cristo }\end{array}$ & $\mathrm{BC}$ & In. C & $\begin{array}{c}\text { Products/ } \\
\text { Perspectives / } \\
\text { Persons }\end{array}$ \\
\hline 12 & $\begin{array}{c}\text { A Discussion about } \\
\text { Festivals/ Folk Music }\end{array}$ & $\mathrm{Lc}$ & $\begin{array}{l}\mathrm{SC} \& \\
\text { In.C }\end{array}$ & $\begin{array}{c}\text { Products/ } \\
\text { Perspectives }\end{array}$ \\
\hline 13 & $\begin{array}{c}\text { A Talk about Aisha } \\
\text { Abderrahman/ Florence } \\
\text { Nightingale/ the Queen of } \\
\text { the Air }\end{array}$ & $\mathrm{BC}$ & $\mathrm{TC}$ & $\begin{array}{l}\text { Practices/ } \\
\text { Perspectives } \\
\text { /Persons }\end{array}$ \\
\hline 14 & $\begin{array}{c}\text { A Radio Program about } \\
\text { Graham Greene/ Travels } \\
\text { with my Aunt }\end{array}$ & $\mathrm{BC}$ & $\mathrm{TC}$ & $\begin{array}{c}\text { Practices/ } \\
\text { Perspectives/ } \\
\text { Persons }\end{array}$ \\
\hline 15 & $\begin{array}{c}\text { A Conversation about e- } \\
\text { books/ The History of Papers }\end{array}$ & $\mathrm{BC}$ & In. $\mathrm{C}$ & $\begin{array}{c}\text { Products/ } \\
\text { Perspectives }\end{array}$ \\
\hline 16 & $\begin{array}{c}\text { A Job Interview/ Sadek } \\
\text { Shalabi }\end{array}$ & $\mathrm{Lc}$ & $\mathrm{SC}$ & $\begin{array}{c}\text { Practices/Perspectiv } \\
\text { es/ Persons }\end{array}$ \\
\hline 17 & $\begin{array}{c}\text { A Talk about John } \\
\text { Steinbeck/ The Pearl: A } \\
\text { Story of Greed }\end{array}$ & $\mathrm{BC}$ & In. $\mathrm{C}$ & $\begin{array}{c}\text { Products/Perspectiv } \\
\text { es }\end{array}$ \\
\hline 18 & $\begin{array}{c}\text { People's Experiences of } \\
\text { Educational Courses/ Tarek } \\
\text { and Nahla }\end{array}$ & Lc & $\mathrm{SC}$ & $\begin{array}{c}\text { Practices/Perspectiv } \\
\text { es/ Persons }\end{array}$ \\
\hline
\end{tabular}


In terms of theme reference and as shown in figure 1, both of $\mathrm{BC}$ and $\mathrm{Lc}$ are present in the textbook. With a top number of 15 units, BC immoderately exceeds Lc (3 units) which came below the average of 9 units.

\section{Figure 1. Theme reference in texts}

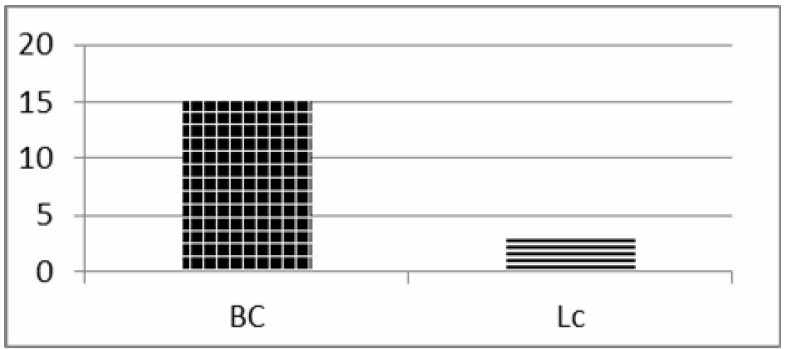

In relation to content reference and as displayed in figure 2 , the three types of culture, namely, SC, TC and In.C are present in the textbook. With a top number of 9 units, In.C ranks highest. Meanwhile, SC (6 units) is only marginally higher than TC (5 units). In spite of their presence, both of SC and TC are below average representation.

\section{Figure 2. Content reference in texts}

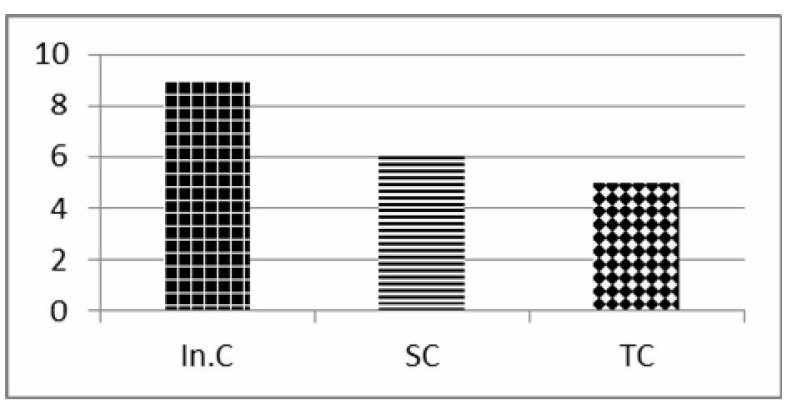

As to dimensions and as shown in figure 3, four types have emerged: products, practices, perspectives and persons. With a top number of 18 , the perspectives dimension comes in the first position. There follows the products dimension with 11 units. In the third position, there comes the persons dimension 


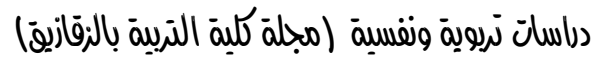

with 9 units. Although the practices dimension scored lowest with 7 units, it is still very close to the third position. The communities dimension is missing.

Figure 3. Dimensions in texts

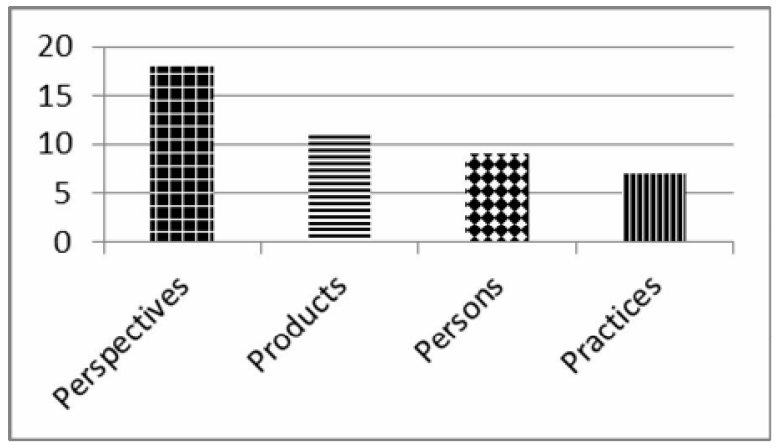

\subsection{Illustrations}

Table 3 and figure 4 indicate the presence of the four types of illustrations, namely, pictures with culture specific reference to native culture (PCSR), free reference (PCFR), general reference (PCGR), and foreign cultures reference (PTCR). The highest score goes to PCGR with 77 out of 206 pictures and a mean of 4.27 pictures per unit. In the second position come PCFR and PTCR with, respectively, 50 and 51 pictures out of 206 and 2.83 and 2.77 as means. The last position goes to PCSR with a sum of 20 pictures out of 206 and a mean of 1.11 .

Table 3. Picture reference

\begin{tabular}{|c|c|c|c|c|c|}
\hline Unit & NB & PCSR & PCFR & PCGR & PTCR \\
\hline $\mathbf{1}$ & 11 & 0 & 7 & 3 & 1 \\
\hline $\mathbf{2}$ & 11 & 2 & 3 & 2 & 4 \\
\hline $\mathbf{3}$ & 14 & 0 & 10 & 0 & 4 \\
\hline $\mathbf{4}$ & 7 & 1 & 2 & 4 & 0 \\
\hline
\end{tabular}


The intercultural competence savoirs Dr Samia Kara

\begin{tabular}{|c|c|c|c|c|c|}
\hline Unit & NB & PCSR & PCFR & PCGR & PTCR \\
\hline $\mathbf{5}$ & 10 & 1 & 2 & 2 & 5 \\
\hline $\mathbf{6}$ & 17 & 0 & 4 & 10 & 3 \\
\hline $\mathbf{7}$ & 11 & 6 & 1 & 4 & 0 \\
\hline $\mathbf{8}$ & 8 & 0 & 1 & 2 & 5 \\
\hline $\mathbf{9}$ & 14 & 0 & 0 & 9 & 5 \\
\hline $\mathbf{1 0}$ & 12 & 0 & 6 & 6 & 0 \\
\hline $\mathbf{1 1}$ & 9 & 0 & 0 & 7 & 2 \\
\hline $\mathbf{1 2}$ & 23 & 7 & 5 & 11 & 0 \\
\hline $\mathbf{1 3}$ & 12 & 2 & 0 & 3 & 7 \\
\hline $\mathbf{1 4}$ & 10 & 0 & 0 & 4 & 6 \\
\hline $\mathbf{1 5}$ & 9 & 0 & 7 & 2 & 0 \\
\hline $\mathbf{1 6}$ & 10 & 1 & 1 & 6 & 2 \\
\hline $\mathbf{1 7}$ & 9 & 0 & 1 & 5 & 3 \\
\hline $\mathbf{1 8}$ & 9 & 0 & 1 & 5 & 3 \\
\hline Book & 206 & 20 & 51 & 77 & 50 \\
\hline Mean & 11.44 & 1.11 & 2.83 & 4.27 & 2.77 \\
\hline
\end{tabular}

Figure 4. Picture reference

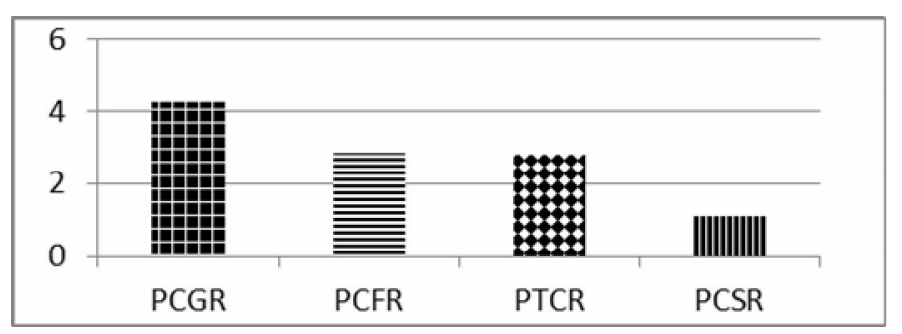




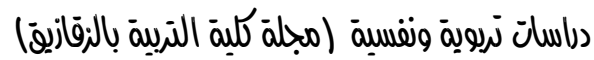

\subsection{Activities/tasks}

In reference to students' active engagement via activities/ tasks embodied in the critical thinking section of each unit, table 4 and figure 5 show that the latter do exist with a total number of 380 tasks wherein students are required to refer to the three types of culture, explicitly, SC, TC and In.C. With a top frequency of 17, In.C ranks first. Then, SC follows with 13. Finally, TC comes in the last position with a frequency of 8 .

\section{Table 4. Student's active engagement}

\begin{tabular}{|c|l|l|}
\hline Page & \multicolumn{1}{|c|}{ Activity/Task } & $\begin{array}{c}\text { Active } \\
\text { Engagement }\end{array}$ \\
\hline 4 & $\begin{array}{l}\text { Countries spend a lot of money on space } \\
\text { exploration. What do you think is their main reason } \\
\text { for doing this? }\end{array}$ & $\begin{array}{l}\text { reference } \\
\text { to In.C }\end{array}$ \\
\hline 4 & $\begin{array}{l}\text { How has technology improved the lives of people in } \\
\text { your country over the last 50 years? Think of these } \\
\text { areas of life: Transport-Communications- Health- } \\
\text { Education- Work-Homes }\end{array}$ & $\begin{array}{l}\text { reference } \\
\text { to SC }\end{array}$ \\
\hline 14 & $\begin{array}{l}\text { Using the internet or a library, find out how space } \\
\text { technology has changed our everyday lives }\end{array}$ & $\begin{array}{l}\text { How can cooperation between countries help to } \\
\text { solve energy problems? } \\
\text { to In.C }\end{array}$ \\
\hline 24 & $\begin{array}{l}\text { What do you understand by the father of the modern } \\
\text { short story and the novel in Egypt? }\end{array}$ & $\begin{array}{l}\text { reference } \\
\text { to In.C } \\
\text { to SC }\end{array}$ \\
\hline 24 & $\begin{array}{l}\text { In what ways does reading literature improve your } \\
\text { education? Think of the following: language and } \\
\text { vocabulary- your own experiences- other people's } \\
\text { experiences- different cultures- unusual or different } \\
\text { situations? }\end{array}$ & $\begin{array}{l}\text { reference } \\
\text { to In.C }\end{array}$ \\
\hline 34 & $\begin{array}{l}\text { Egypt has many palm trees. What products come } \\
\text { from palm trees? }\end{array}$ & $\begin{array}{l}\text { reference } \\
\text { to SC }\end{array}$ \\
\hline
\end{tabular}


The intercultural competence savoirs

Dr Samia Kara

\begin{tabular}{|c|c|c|}
\hline Page & Activity/Task & $\begin{array}{c}\text { Active } \\
\text { Engagement }\end{array}$ \\
\hline 44 & $\begin{array}{l}\text { Why was it so important for Egypt to build the } \\
\text { Aswan Dam? }\end{array}$ & $\begin{array}{l}\text { reference } \\
\text { to } \mathrm{SC}\end{array}$ \\
\hline 44 & $\begin{array}{l}\text { What effects do huge engineering projects like the } \\
\text { Aswan Dam have on the people who live in the } \\
\text { area? }\end{array}$ & $\begin{array}{l}\text { reference } \\
\text { to } \mathrm{SC}\end{array}$ \\
\hline 44 & $\begin{array}{l}\text { Do you agree that it is unthinkable that countries } \\
\text { should lose ancient monuments? Why/Why not? }\end{array}$ & $\begin{array}{l}\text { reference } \\
\text { to In.C }\end{array}$ \\
\hline 44 & $\begin{array}{l}\text { Historical monuments are sometimes threatened by } \\
\text { new engineering or building projects. What other } \\
\text { things may threaten them? }\end{array}$ & $\begin{array}{l}\text { reference } \\
\text { to In.C }\end{array}$ \\
\hline 44 & $\begin{array}{l}\text { Is it ever right for historical monuments to be } \\
\text { destroyed? }\end{array}$ & $\begin{array}{l}\text { reference } \\
\text { to In.C }\end{array}$ \\
\hline 44 & $\begin{array}{l}\text { How do you think we should protect historical } \\
\text { monuments? }\end{array}$ & $\begin{array}{l}\text { reference } \\
\text { to In.C }\end{array}$ \\
\hline 49 & $\begin{array}{l}\text { Do you agree that human beings have good and evil } \\
\text { sides? }\end{array}$ & $\begin{array}{l}\text { reference } \\
\text { to In.C }\end{array}$ \\
\hline 49 & $\begin{array}{l}\text { What does the writer mean when he says that good } \\
\text { and evil sides are always in conflict? }\end{array}$ & $\begin{array}{l}\text { reference } \\
\text { to } \mathrm{TC}\end{array}$ \\
\hline 49 & $\begin{array}{l}\text { Why do you think Dr Jekyll's colleagues disagree } \\
\text { with his ideas and disapprove of his research? Do } \\
\text { you think his research is a good idea? }\end{array}$ & $\begin{array}{l}\text { reference } \\
\text { to } \mathrm{TC}\end{array}$ \\
\hline 49 & Why do you think Mr Hyde behaves in an evil way? & $\begin{array}{l}\text { reference } \\
\text { to } \mathrm{TC}\end{array}$ \\
\hline 49 & $\begin{array}{l}\text { What do you think is the main message of Dr Jekyll } \\
\text { and Mr Hyde? }\end{array}$ & $\begin{array}{l}\text { reference } \\
\text { to } \mathrm{TC}\end{array}$ \\
\hline 54 & Could you live in a place as windy as this? & $\begin{array}{l}\text { reference } \\
\text { to } \mathrm{TC}\end{array}$ \\
\hline
\end{tabular}




\begin{tabular}{|c|c|c|}
\hline Page & Activity/Task & $\begin{array}{c}\text { Active } \\
\text { Engagement }\end{array}$ \\
\hline 54 & $\begin{array}{l}\text { How do you think the wind affects the people who } \\
\text { live in Port Martin? }\end{array}$ & $\begin{array}{l}\text { reference } \\
\text { to } \mathrm{TC}\end{array}$ \\
\hline 54 & $\begin{array}{l}\text { What other kinds of extreme weather are there? } \\
\text { Have you any experience of any of these types of } \\
\text { weather? Tell a partner about it. }\end{array}$ & $\begin{array}{l}\text { reference } \\
\text { to } \mathrm{SC}\end{array}$ \\
\hline 54 & $\begin{array}{l}\text { Storm chasers are people who find and follow } \\
\text { storms. Why do you think they do this? }\end{array}$ & $\begin{array}{l}\text { reference } \\
\text { to } \mathrm{TC}\end{array}$ \\
\hline 54 & $\begin{array}{l}\text { What are the dangers of chasing a storm? Do you } \\
\text { think people should put their lives in danger like } \\
\text { this? Give your reasons. Use the language below. }\end{array}$ & $\begin{array}{l}\text { reference } \\
\text { to } \mathrm{TC}\end{array}$ \\
\hline 64 & $\begin{array}{l}\text { In your opinion, what are the most important } \\
\text { scientific discoveries of the last } 100 \text { years? }\end{array}$ & $\begin{array}{l}\text { reference } \\
\text { to In.C }\end{array}$ \\
\hline 64 & $\begin{array}{l}\text { Find out about these important scientists: Fawzia } \\
\text { Fahim- Moustafa Moshara fa- Gregor Mendel- } \\
\text { Isaac Newton - William Harvey - Alexander } \\
\text { Fleming- Nicolaus Copernicus -Ibn Al-Nafis }\end{array}$ & $\begin{array}{l}\text { reference } \\
\text { to } \mathrm{SC}\end{array}$ \\
\hline 74 & $\begin{array}{l}\text { Find out about two of these important scientists: } \\
\text { Fawzia Fahim- Moustafa Mosharafa- Gregor } \\
\text { Mendel- Isaac Newton - William Harvey - } \\
\text { Alexander Fleming- Nicolaus Copernicus -Ibn Al- } \\
\text { Nafis }\end{array}$ & $\begin{array}{l}\text { reference } \\
\text { to In.C }\end{array}$ \\
\hline 69 & $\begin{array}{l}\text { Why do friends sometimes feel envious of each } \\
\text { other? How can you stop these feelings? Why are } \\
\text { friends so important? How can people show that } \\
\text { they value their friends? }\end{array}$ & $\begin{array}{l}\text { reference } \\
\text { to In.C }\end{array}$ \\
\hline 74 & $\begin{array}{l}\text { How would you describe Egyptian music to } \\
\text { someone from another culture? }\end{array}$ & $\begin{array}{l}\text { reference } \\
\text { to } \mathrm{SC}\end{array}$ \\
\hline 74 & $\begin{array}{l}\text { Do people still use music for a purpose, e.g. to sing } \\
\text { babies to sleep? }\end{array}$ & $\begin{array}{l}\text { reference } \\
\text { to In.C }\end{array}$ \\
\hline 74 & How is modern music different from traditional & reference \\
\hline
\end{tabular}


The intercultural competence savoirs

Dr Samia Kara

\begin{tabular}{|c|l|l|}
\hline Page & \multicolumn{1}{|c|}{ Activity/Task } & $\begin{array}{c}\text { Active } \\
\text { Engagement }\end{array}$ \\
\hline 74 & $\begin{array}{l}\text { If you could learn to play a traditional musical } \\
\text { instrument, which would you choose? Give your } \\
\text { reasons. }\end{array}$ & $\begin{array}{l}\text { reference } \\
\text { to SC }\end{array}$ \\
\hline 84 & $\begin{array}{l}\text { What jobs can women do today that they could not } \\
\text { do 50 years ago? }\end{array}$ & $\begin{array}{l}\text { reference } \\
\text { to SC }\end{array}$ \\
\hline 84 & $\begin{array}{l}\text { Do you think there are some jobs that only men or } \\
\text { only women should do? }\end{array}$ & $\begin{array}{l}\text { reference } \\
\text { to SC }\end{array}$ \\
\hline 84 & $\begin{array}{l}\text { Can you think of other women who have worked } \\
\text { hard for their community or their country? }\end{array}$ & $\begin{array}{l}\text { reference } \\
\text { to SC }\end{array}$ \\
\hline 89 & $\begin{array}{l}\text { How can travel and experiences of other cultures } \\
\text { change people? }\end{array}$ & $\begin{array}{l}\text { reference } \\
\text { to In.C }\end{array}$ \\
\hline 109 & $\begin{array}{l}\text { Which other cultures would you like to experience? } \\
\text { Why? }\end{array}$ & $\begin{array}{l}\text { reference } \\
\text { to In.C }\end{array}$ \\
\hline 104 & $\begin{array}{l}\text { What kind of work do you hope to do when you } \\
\text { finish your education? }\end{array}$ & $\begin{array}{l}\text { reference } \\
\text { to SC }\end{array}$ \\
\hline
\end{tabular}

Figure 5. Students' active engagement

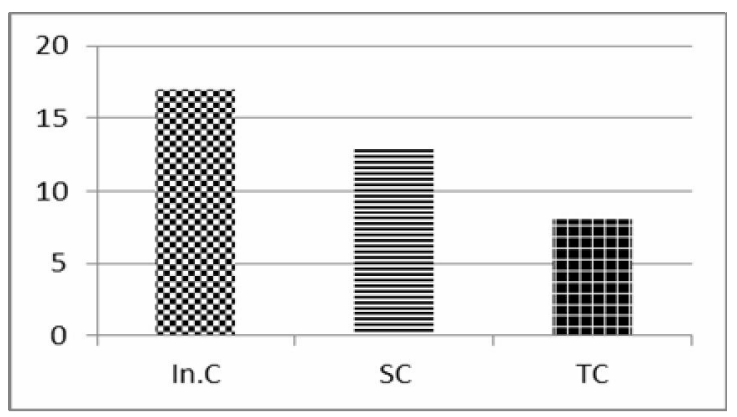

- 376 - 
العدد (ب - 1) الجزء الثاني ابريل 9 1 • ؟

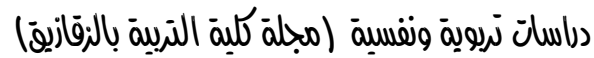

\section{Discussion}

The purpose of this paper was to probe the existence and magnitude of intercultural competence savoirs in 'Hello! English for Secondary Schools' textbook through the investigation of its goals, texts, activities/tasks and illustrations.

\subsection{Goals and objectives}

The results indicate that in terms of goals/objectives, the textbook does include the intention of developing an intercultural attitude as it is standards-based communicative approach oriented. The standards-based approach in foreign language teaching advocates the use of standards (quality levels) grouped under five umbrellas called the five Cs, namely, communication, cultures, connections, comparisons and communities (Rosenbush, 1997). It must be noted that the Egyptian standards embody these umbrellas. However, the connection umbrella which is mainly related to making links between the subject of English and other subjects is not included.

The cultures umbrella is mainly concerned with culture in terms of its products, practices and perspectives interrelationships. Thus, it hypothetically targets the intercultural attitude in terms of awareness. This being said, the purpose is embodied in the cultures umbrella in terms of the 'products', 'practices' and 'perspectives' dimensions (Moran, 2001).

\subsection{Texts}

The results show that in relation to texts and in terms of theme reference, BC (13 units) immoderately exceeds Lc (9 
units). Indeed, the amount of $\mathrm{BC}$ is three times that of $\mathrm{Lc}$. Although BC is important, Lc should have been given the same importance to satisfy the criterion of cultural topic diversity (Cunningsworth, 1995; cited in Liu, 2016) that requires the inclusion of diverse social aspects as natural communication situations wherein intercultural elements are encountered. One probable reason behind this drawback is the fact that the textbook is standards-based approach oriented. That is to say, although it caters for intercultural ingredients via the culture umbrella, it also looks for interdisciplinary knowledge provided by other subjects through the connections umbrella. For example, 'space travel' might call forth rockets and be related to physics, 'Aisha Abderrahman' is an Egyptian writer who is encountered in Arabic, and Alexander Dumas is a French writer who might be met in French. To be more critical, this imbalance makes the book somehow unrealistic as to students' intercultural knowledge needs. In fact, when a student goes on the net, for instance, and connects with international communities, it is very improbable that $\mathrm{s} /$ he encounters global peers talking about space unless they are studying the same topics. S/he will see them performing language functions such as congratulating one another on national/ religious occasions, discussing their preferred soccer teams, fashion icons and best singers. One may note that there is a whole section for communication practice in each unit; however, the claim here is not about the goal itself but about the context. When students discuss the space topic, they may take advantage of it in the physics course and less probably in an international socializing context. Besides, the problem is not in relation to $\mathrm{BC}$ per se; the concern is rather about the much smaller amount of Lc situations.

Always in relation to texts and in terms of content reference, the results demonstrate that In.C (9 units) ranks 
highest and is followed by SC (6 units) which is marginally higher than TC (5 units). Of course, In.C is granted a lion's share and again this is related to the connections umbrella explained earlier. However, the textbook succeeds in relation to cultural information as per Chen's (2012; cited in Liu, 2016) criterion of types of culture whereby various cultures are supposed to be present. A good point worth mentioning is the fact that In.C does appear related with SC in three units, namely, unit 1, unit 2 and unit 17. This intertwining of cultural elements from a native culture and a non-native one serves the IC savoirs.

The results indicate also that in terms of dimensions and with a top number of 18 units, the perspectives dimension comes in the first position and is followed by the products dimension with 11 units, the persons dimension with 9 units and the practices dimension with 7 units. The communities dimension is inexistent. The perspective dimension is not overtly announced but implied via the instructions of the communication section as well as inside the texts and the transcripts. The explanation of its presence in all the units lies in the fact that it is tied to products (11 units) and practices (7 units). This fulfils the culture umbrella requirements of the standards-based approach whereby it is required that perspectives be related to both (Rosenbush, 1997). As to products and practices themselves and knowing that the former is linked to $\mathrm{BC}$ and that the latter is in connection with Lc, it is but normal that these two dimensions come in the same order of importance as $\mathrm{BC}$ and $\mathrm{Lc}$ in relation to theme reference for the same abovementioned reasons. For its part, the persons dimension which is embodied by individuals representing a culture is present in connection with the three types of content reference. It is linked to SC (units 4, 12, 16 and 18), TC (units 1, 5, 8, 12, 14, and17) and In.C (unit 11). The persons dimension is $\mathrm{BC}$ in 8 units (units $1,4,5,8,11,12,14$, 
16 , and 17) and is Lc in only one unit (unit 18). This is also corroborated by the absence of the communities dimension. Again here, the standards-based approach connections umbrella might be the main reason. For a second time, the textbook succeeds in fulfilling Chen's (2012; cited in Liu, 2016) criterion in relation to cultural information.

\subsection{Illustrations}

In terms of illustrations and as per Ajideh and Panahi's (2016) classification, the results of the analysis show that the highest score is realised by PCGR with 77 out of 206 pictures and a mean of 4.27 pictures per unit ; following it, there comes PCFR and PTCR with, respectively, 50 and 51 pictures out of 206 and 2.83 and 2.77 as means. The last position is occupied by PCSR with a sum of 20 pictures out of 206 and a mean of 1.11 . Therefore, the pictures that vehicle an input common to all cultures earned a lion's share. Although those which target English and non-English culture as well as native culture came in the third and fourth positions respectively, their ratios are still important. Considering the visual power of pictures as supporters of textual content, the textbook gives them enough room to accomplish their target in relation to IC savoirs. In fact and besides the fact that all types are present, the moderate majority of pictures refer to all cultures. Consequently, the intercultural element is to be considered as present.

\subsection{Activities/tasks}

In addition and in relation to students' active engagement via activities/ tasks (Reinemann, 2009; cited in Liu, 2016) provided in the critical thinking section, the results indicate that 
with a total number of 38 engaging tasks, reference is made to In.C (17), SC (13) and TC (8). Thus, students are encouraged to actively take part in the comprehension of cultural notions in the texts that are in relation to the three types of culture. It also helps them consolidating their already text mediated cultural information. Consequently, the activities/ tasks contribute to the IC savoirs.

\subsection{Synopsis}

In summary, the textbook analysis clearly shows that it goes hand in hand with the IC savoirs in terms of goals and objectives, texts, illustrations and activities/ tasks. However, a problematic area resides in the $\mathrm{BC}$ vs. Lc imbalance which might be seen as probably due to the connections dimension requirement of the adopted standards-based approach but which is not a requirement of the Egyptian standards.

\section{Conclusion}

The starting point of this paper was a question raised in relation to the existence and magnitude of the IC savoirs in the Egyptian secondary level English textbook at the level of goals/objectives, texts, activities/tasks and teaching aids (illustrations). The analysis has demonstrated that this ingredient is evidently present in terms of intercultural attitude enhancement (goals and objectives), cultural topics and information (texts and transcripts), students' active engagement (activities/ tasks) and teaching aids/ illustrations (picture references). However the same analysis has also demonstrated that the little culture ingredient has been marginalised for the benefit of the big culture as part of the requirements of the standards-based approach connections umbrella. This marginalisation attained all levels as all the analysis ingredients are interconnected. 
The standards-based approach in teaching languages does not go against the IC savoirs. On the contrary, it does open horisons for its application. However, the thematic organisation of the textbook made the latter rely on topics and this is how the problem emerged and came in relation to the choices made of the texts that satisfied the connections umbrella at the expense of the cultures one. As much of the literature produced in intercultural competence is somehow recent, and considering that the textbook was published in 2010, there emerges a need to review it in light of rebalancing the components in favour of a more Lc. oriented view and following the requirements of the Egyptian standards which do not encompass the connections umbrella.

\section{References}

Ahmed , F. and Narcy-Combes, M. F. (2011). An analysis of textbooks from a cultural point of view. TESOL Journal, 5, 21 37.

Ajideh, P. \& Panahi, M. (2016). An analysis of culture related content in English textbooks for Iranian students entitled "Prospect" and |Vision" series. International Journal of Language and linguistics, 3 (6), 87-93.

El-Araby, S. El-Naggar, Z. Gheith, A., ElDib, M. Mostafa, A. ElSaid, M. Salah-Al_Din, Y. Hasan, A. Farghaly, G. Abdullah, M. ElSouefi, N. Hegazy, M. Abdulaal, A., ElMehallawy, M. Siam, S. Bekhit, M. 2012. The National Curriculum Framework for English as a Foreign Language (EFL) Grades 1-12. Ministry of Education. Egypt.

Arabski, J \& Wojtaszek, A. 2011. Chapter 1: Introduction. In Arabski, J \& Wojtaszek, A. (Eds.). Aspects of Culture in Second 


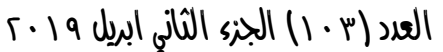

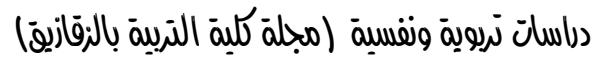

Language Acquisition and Foreign Language Learning. Springer Heidelberg.

Arasaratnam, L. A. (2016). Communication theory, communication and culture: Interpersonal communication. In Oxford Research Encyclopedia of Communication, retrieved on 15 October, 2017: http://communication.oxfordre.com/view/10.1093/acrefore/9780 190228613.001.0001/acrefore-9780190228613-e-68

Baker, W. (2009). The cultures of English as a lingua franca. TESOL Quarterly, 43(4), 567-592.

Brooks, N. (1968). Teaching culture in the foreign language classroom. Foreign Language Annals: 204-217.

Byram, M. (1997). Teaching and assessing intercultural communicative competence. Clevedon: Multilingual Matters.

Carley, K. (1990). Content analysis. In R.E. Asher (Ed.), The Encyclopedia of Language and Linguistics. Edinburgh: Pergamon Press.

Cortazzi, M \& Jin, L.X. (1999). Cultural mirrors: materials and methods in the EFL classroom. In E. Hinkel, (ed.), Culture in Second Language Teaching and Learning. Cambridge: Cambridge University Press, 196-219.

Creswell, J.W. (2011). Controversies in mixed methods research. In N. K. Denzin \& Y. S. Lincoln (Eds.), The sage handbook of qualitative research ( $4^{\text {th }}$ ed.), 269-284. Los Angeles, CA: Sage.

Davydova, J. (2012). Englishes in the outer and expanding circles: A comparative study. World Englishes, 31 (3), 366-385.

Deardorff , D.K. (2011). Assessing intercultural competence. New Directions for Institutional Research, 149, 65-79. Wiley Periodicals. DOI: 10.1002/ir.381. 
Haines, S. \& Dallas D. 2010. Hello! English for secondary schools: Year three. Egyptian International Publishing Company- Longman.

Hofstede, G. (1980). Culture's consequences: International difference in work-related values. Thousand Oaks, CA: SAGE Publications.

Homayounzadeh, M. \& Sahragard, R. (2015). An intercultural approach to textbook evaluation: A case of Top Notch and Summit Series. International Journal of Applied Linguistics and English Literature, 4(1), 199-208.

Karyshev, A.D., Karysheva, O.A. \& Ivanova, E.A. (2014). College students' intercultural competence and interethnic tolerance. In Russian Education and Society, 56 (9), 3-26.

Kim, S.Y. \& Paek, J.A. (2015). An analysis of culture-related content in English textbooks. Linguistic Research, 32 (special edition), 83-104.

Kramsch, C. (1993). Culture and context in language teaching. OUP.

Lafayette, R. (1997). Integrating the teaching of culture into the foreign language classroom. In P. R. Heusinkveld (Ed.), Pathways to culture: Reading on teaching culture in the foreign language class (pp.119-148). Yarmouth, ME: Intercultural Press.

Lario de Oñate, M., \& Vázquez Amador, M. (2013). The intercultural component in Business English textbooks. Ibérica, Revista de la Asociación Europea de Lenguas para Fines Especificos, (26), 171-194.

Liu, K. (2016). Prioritizing criteria for evaluating cultural contents in EFL textbooks through AHP. Journal of language teaching and research, 7(5), 841-850. 
Lomicka, L. L. (2015). An intercultural approach to teaching and learning French. French Review, 82 (6), 1227-1243.

López-Rocha, S. (2016). Intercultural communicative competence: creating awareness and promoting skills in the language classroom. In C. Goria, O. Speicher, \& S. Stollhans (Eds), Innovative Language Teaching and Learning at University: Enhancing Participation and Collaboration, 105-111. Dublin:

Research-publishing.net. http://dx.doi.org/10.14705/rpnet.2016.000411.

Matveev, A. V., \& Merz, M. Y. (2012). Intercultural competence assessment: what are its key dimensions across assessment tools? In Toward Sustainable Development Through Nurturing Diversity: Selected Papers from the Twenty-First Congress of the International Associate for Cross-Cultural Psychology, 141153, retrieved on 16 October, 2017: http://www.iaccp.org/sites/default/files/stellenbosc h_pdf/Matveev.pdf

Nizegorodcew, A. 2011. Chapter 2: Understanding culture through a lingua franca. In Arabski, J \& Wojtaszek, A. (Eds.). Aspects of Culture in Second Language Acquisition and Foreign Language Learning. Springer Heidelberg.

Rosenbush, M.H. 1997. Bringing the standards into the classroom: A teacher's guide, second edition. National K12 foreign language resource centre. Iowa State University.

Stannard, R. n.d. Hello! English for secondary schools: Year three. Egyptian International Publishing Company- Longman.

Spitzberg, B. \& Changnon, G. (2009). Conceptualizing intercultural competence. The Sage Handbook of Intercultural Competence. 2-52. Sage.

UNESCO. 2013. Intercultural competences: Conceptual and operational framework. UNESCO. 